\title{
Enteric methane emissions and lactational performance of Holstein cows fed different concentrations of coconut oil
}

\author{
M. Hollmann, ${ }^{\star}$ W. J. Powers, ${ }^{\star} \dagger$ A. C. Fogiel, ${ }^{*}$ J. S. Liesman, ${ }^{\star}$ N. M. Bello, ${ }^{*}{ }^{1}$ and D. K. Beede ${ }^{\star 2}$ \\ *Department of Animal Science, \\ †Department of Biosystems and Agricultural Engineering, \\ $\ddagger$ College of Agriculture and Natural Resources Statistical Consulting Center, Michigan State University, East Lansing 48824
}

\begin{abstract}
To determine if dietary medium-chain fatty acids (FA; $\mathrm{C}_{8}$ to $\mathrm{C}_{14}$ ) may mitigate enteric methane emissions, 24 cows were blocked by body size $(\mathrm{n}=2)$ and randomly assigned to 1 sequence of dietary treatments. Diets were fed for $35 \mathrm{~d}$ each in 2 consecutive periods. Diets differed in concentrations of coconut oil (CNO; $\sim 75 \%$ mediumchain FA): 0.0 (control) or 1.3, 2.7, or $3.3 \% \mathrm{CNO}$, dry matter basis. The control diet contained $50 \%$ forage ( $74 \%$ from corn silage), $16.5 \%$ crude protein (60\% from rumen-degradable protein), $34 \%$ neutral detergent fiber (NDF; $71 \%$ from forage), and $28 \%$ starch, dry matter basis. Data and sample collections were from d 29 to 35 in environmentally controlled rooms to measure methane $\left(\mathrm{CH}_{4}\right)$ production. Methane emitted was computed from the difference in concentrations of inlet and outlet air and flux as measured 8 times per day. Control cows emitted $464 \mathrm{~g}$ of $\mathrm{CH}_{4} / \mathrm{d}$, consumed 22.9 $\mathrm{kg}$ of $\mathrm{DM} / \mathrm{d}$, and produced $34.8 \mathrm{~kg}$ of solids-corrected milk/d and $1.3 \mathrm{~kg}$ of milk fat $/ \mathrm{d}$. Treatment with 1.3 , 2.7 , or $3.3 \%$ dietary CNO reduced $\mathrm{CH}_{4}(449,291$, and $253 \mathrm{~g} / \mathrm{d}$, respectively), but concomitantly depressed dry matter intake $(21.4,17.9$, and $16.2 \mathrm{~kg} / \mathrm{d}$, respectively), solids-corrected milk yield $(36.3,28.4$, and $26.8 \mathrm{~kg} / \mathrm{d}$, respectively), and milk fat yield $(1.4,0.9$, and $0.9 \mathrm{~kg} / \mathrm{d}$, respectively). The amount of NDF digested in the total tract decreased with increased dietary $\mathrm{CNO}$ concentrations; thus, $\mathrm{CH}_{4}$ emitted per unit of NDF digested rose from 118 to 128,153 , and $166 \mathrm{~g} / \mathrm{kg}$ across CNO treatments. Dietary CNO did not significantly affect apparent digestibility of $\mathrm{CP}$ but increased apparent starch digestibility from 92 to $95 \%$. No $\mathrm{FA} \mathrm{C}_{10}$ or shorter were detected in feces, and apparent digestibility decreased with increasing FA chain length. Coconut oil concentrations of 2.7 or $3.3 \%$ decreased yields of milk $\mathrm{FA}<\mathrm{C}_{12}$ and $>\mathrm{C}_{14}$. The highest milk fat concentration $(3.69 \%$;
\end{abstract}

\footnotetext{
Received September 2, 2011.

Accepted December 21, 2011.

${ }^{1}$ Current address: Department of Statistics, Kansas State University, 108C Dickens Hall, Manhattan 66506.

${ }^{2}$ Corresponding author: beede@msu.edu
}

$1.3 \% \mathrm{CNO}$ ) was due to the greatest yields of $\mathrm{C}_{12}$ to $\mathrm{C}_{16}$ milk FA. Milk FA concentrations of $\mathrm{C}_{18: 2 \text { trans-10,cis-12 }}$ were related to increased dietary $\mathrm{CNO}$ concentrations and presumably to depressed ruminal NDF digestion. Moderate dietary CNO concentrations (e.g., 1.3\%) may benefit lactational performance; however, CNO concentrations greater than or equal to $2.7 \%$ depressed dry matter intake, milk yield, milk fat yield, and NDF utilization. If mitigation of enteric $\mathrm{CH}_{4}$ emissions is due to decreased digestion of dietary NDF, then this will lessen a major advantage of ruminants compared with nonruminants in food-production systems. Thus, CNO has limited use for enteric $\mathrm{CH}_{4}$ mitigation in lactating dairy cows.

Key words: enteric methane, medium-chain fatty acid, neutral detergent fiber digestibility, lactating dairy cow

\section{INTRODUCTION}

Currently, mitigation of enteric methane $\left(\mathbf{e C H}_{\mathbf{4}}\right)$ emissions from ruminant livestock is being researched as a mechanism to decrease agricultural greenhouse gas emissions. A high-producing dairy cow (>30 $\mathrm{kg}$ of $3.5 \%$ FCM yield/d) generates from 390 to $650 \mathrm{~g}$ of $\mathrm{eCH}_{4} / \mathrm{d}$ (Johnson et al., 2002; Aguerre et al., 2011). Enteric $\mathrm{CH}_{4}$ emissions correlate positively to the amount of DM digested in the rumen, which itself depends on dietary fermentability, DMI as a multiple of maintenance (Blaxter and Clapperton, 1965), and passage rates of ingested particles. Thus, less-fermentable or slowly fermenting nutrients (e.g., NDF) are affected more than highly fermentable nutrients (e.g., starch). Therefore, methanogenesis (e.g., as a result of NDF digestion) is decreased in favor of propionate production (e.g., from starch digestion) in high-producing dairy cows fed a highly fermentable diet at DMI 3 or more times the maintenance level.

An additional reason for differences in $\mathrm{eCH}_{4}$ emissions is that dietary FA replace fermentable carbohydrates such as NDF or starch, which, in turn, can reduce $\mathrm{eCH}_{4}$ emissions. Dietary FA are resistant to digestion in the 
rumen, in contrast to ruminally fermentable carbohydrates. Moreover, dietary FA can shift pathways of ruminal fermentation to partially mitigate $\mathrm{eCH}_{4}$ emissions. Specifically, each percentage unit of dietary FA reduced $\mathrm{eCH}_{4}$ emissions by $5.6 \%$ per unit of DMI across multiple experiments with different ruminant species without apparent differences between dietary mediumchain FA (MCFA; $\mathrm{C}_{8}$ to $\mathrm{C}_{14}$ ) and long-chain FA (LCFA; $\mathrm{C}_{16}$ to $\mathrm{C}_{18}$; Beauchemin et al., 2008). However, individual saturated $\mathrm{FA}$ differ in their suppression of $\mathrm{eCH}_{4}$ emissions based on chain length (e.g., $\mathrm{C}_{12: 0}>\mathrm{C}_{14: 0}$ $>\mathrm{C}_{10: 0}, \mathrm{C}_{16: 0}$, or $\mathrm{C}_{18: 0}$; Blaxter and Czerkawski, 1966). Therefore, coconut oil (CNO; $75 \%$ MCFA) may be considered as a potential dietary ingredient to reduce $\mathrm{eCH}_{4}$ (Machmüller, 2006). The current classification of MCFA is based on chain length of FA, the potential to reduce $\mathrm{eCH}_{4}$ emissions, and their relatively rare occurrence in most feedstuffs. Thus, the current classification of MCFA differs from the physiological classification of MCFA, which does not include $\mathrm{C}_{14}$ and not $\mathrm{C}_{12}$.

Indeed, increased $\mathrm{CNO}$ concentration in diets offered to beef heifers reduced $\mathrm{eCH}_{4}$ emissions linearly by $8 \%$ per percentage unit of dietary CNO (Jordan et al., 2006). Additionally, $\mathrm{eCH}_{4}$ emitted per unit of $\mathrm{DM}$ digested decreased linearly as dietary lauric acid $\left(\mathrm{C}_{12: 0}\right)$ concentrations increased. However, feeding the equivalent of $4.6 \% \mathrm{CNO}$ or more (DM basis; Jordan et al., 2006; Reveneau, 2008; Hollmann and Beede, 2011), or $1.2 \%$ or more $\mathrm{C}_{12: 0}$ (Dohme et al., 2004; Hristov et al., 2011) markedly decreased DMI in cattle. In contrast, feeding lower dietary concentrations of CNO (Jordan et al., 2006; Hristov et al., 2009) or $\mathrm{C}_{12: 0}$ (Hristov et al., 2009) or feeding myristic acid $\left(\mathrm{C}_{14: 0}\right.$; Dohme et al., 2004; Odongo et al., 2007) did not decrease energy intake. Two major questions remain unanswered about the effects of feeding CNO or MCFA to high-producing dairy cows: which concentration of CNO or MCFA can be fed without decreasing energy intake and what is the corresponding reduction in $\mathrm{eCH}_{4}$ emissions?

The response in NDF digestibility to dietary CNO may be dose related (Jordan et al., 2006). Dietary MCFA decreased total tract NDF digestibility and the amount of NDF digested in most studies (Sutton et al., 1983; Jordan et al., 2006; Hollmann and Beede, 2012), but not in all (Jordan et al., 2006; Hristov et al., 2009). Meanwhile, dietary MCFA had little effect on apparent digestibilities of dietary starch and CP in any of the aforementioned experiments. Conceptually, in cows fed at multiple levels of maintenance, decreasing digestion of NDF while maintaining digestion of nonfiber carbohydrates (e.g., starch) will decrease $\mathrm{eCH}_{4}$ emissions (Blaxter and Czerkawski, 1966). It is not clear whether or not the decrease in NDF digestion with MCFAcontaining diets causes reduction in $\mathrm{eCH}_{4}$ emissions or, ideally, if a range of dietary $\mathrm{CNO}$ concentrations exist at which $\mathrm{eCH}_{4}$ is reduced without affecting $\mathrm{NDF}$ digestion.

Effects of dietary MCFA on milk yield (MY) likely are secondary responses and relate to DMI and energy intake. Yet, MY response did not always follow DMI response (Külling et al., 2002; Dohme et al., 2004), presumably because of the short duration ( $15 \mathrm{~d}$ ) of feeding MCFA. Furthermore, dietary inclusion of MCFA as part of a TMR initiated milk-fat depression (MFD; Faciola et al., 2008), or exacerbated MFD (Reveneau, 2008; Hollmann and Beede, 2012) by means of a combination of yield reductions of de novo-synthesized milk FA $\left(<\mathrm{C}_{12}\right)$ and preformed milk LCFA (Reveneau, 2008; Hollmann and Beede, accepted). Moreover, MCFA often decreased concentrations of milk protein (Rindsig and Schultz, 1974; Storry et al., 1974; Reveneau, 2008) or lactose (Faciola et al., 2008; Hollmann and Beede, 2012). A decrease in SCM yield (SCMY) can dilute or eliminate potential benefits of reductions in $\mathrm{eCH}_{4}$ emissions.

We are unaware of any reports in which $\mathrm{eCH}_{4}$ emissions of high-producing dairy cows fed different concentrations of CNO have been characterized. Our objective was to identify a dietary CNO concentration for highproducing dairy cows at which the combination of $\mathrm{eCH}_{4}$ emissions, energy intake, NDF digestibility, and SCMY are optimized. We hypothesized that moderate $\mathrm{CNO}$ concentration will reduce $\mathrm{eCH}_{4}$ emissions while maintaining intake, NDF digestibility, and SCMY, whereas greater dietary concentrations of $\mathrm{CNO}$ will depress intake, NDF digestibility, and SCMY.

\section{MATERIALS AND METHODS}

The All University Committee on Animal Use and Care at the Michigan State University (East Lansing) approved all experimental procedures (Approval number 07/07-130-00).

\section{Treatments and Cows}

All dietary concentrations are presented on a DM basis. Four treatment diets were formulated to meet or exceed recommendations (NRC, 2001) and had CNO concentrations of $0.0 \%$ (CNO0), $1.3 \%$ (CNO1.3), $2.7 \%$ (CNO2.7), or 3.3\% (CNO3.3). Dietary ingredients and nutrient compositions are listed in Table 1 and the FA profiles of CNO and diets are listed in Table 2. Dietary CNO and soybean meal partially replaced soy hulls to maintain isonitrogenous diets. Coconut oil was heated to $40^{\circ} \mathrm{C}$ and mixed with nonforage ingredients of the diets. A forage-based mixture was prepared daily and mixed with the respective treatment concentrates 
Table 1. Ingredient and nutrient compositions of experimental diets

\begin{tabular}{|c|c|c|c|c|}
\hline \multirow[b]{2}{*}{ Composition } & \multicolumn{4}{|c|}{ Treatment $^{1}$} \\
\hline & CNO0 & CNO1.3 & CNO2.7 & CNO3.3 \\
\hline \multicolumn{5}{|l|}{ Ingredient, $\%$ of DM } \\
\hline Corn silage $^{2}$ & 36.8 & 36.8 & 36.8 & 36.8 \\
\hline Alfalfa silage $^{3}$ & 7.4 & 7.4 & 7.4 & 7.4 \\
\hline Grass silage $^{4}$ & 5.5 & 5.5 & 5.5 & 5.5 \\
\hline Ground corn & 24.1 & 24.1 & 24.2 & 24.2 \\
\hline Soy hulls & 6.9 & 5.1 & 3.4 & 2.5 \\
\hline $\mathrm{CNO}$ & - & 1.3 & 2.7 & 3.3 \\
\hline Soybean meal $(48 \%$ CP) & - & 0.4 & 0.7 & 0.9 \\
\hline Heat-processed soybean meal ${ }^{5}$ & 9.9 & 9.9 & 9.9 & 9.9 \\
\hline Wheat middlings & 5.5 & 5.5 & 5.5 & 5.5 \\
\hline Corn gluten meal & 0.9 & 0.9 & 0.9 & 0.9 \\
\hline Urea & 0.6 & 0.6 & 0.6 & 0.6 \\
\hline Mineral-vitamin $\operatorname{mix}^{6}$ & 2.5 & 2.5 & 2.5 & 2.5 \\
\hline \multicolumn{5}{|l|}{ Nutrient composition, \% of DM } \\
\hline $\mathrm{DM}(\%$ as fed $)$ & 44.5 & 44.5 & 44.6 & 44.6 \\
\hline $\mathrm{OM}$ & 93.2 & 93.4 & 93.5 & 93.3 \\
\hline NDF & 34.5 & 33.8 & 32.7 & 32.3 \\
\hline Indigestible NDF & 7.6 & 7.7 & 8.5 & 9.0 \\
\hline Forage NDF & 23.8 & 23.8 & 23.8 & 23.8 \\
\hline Starch & 27.6 & 27.5 & 27.8 & 27.7 \\
\hline $\mathrm{EE}$ & 5.4 & 6.3 & 7.4 & 8.0 \\
\hline $\mathrm{CP}$ & 16.5 & 16.4 & 16.7 & 16.4 \\
\hline Rumen-undegradable $\mathrm{CP}^{7}$ & 6.0 & 6.0 & 5.9 & 5.9 \\
\hline Gross energy, Mcal/kg & 4.37 & 4.45 & 4.45 & 4.48 \\
\hline
\end{tabular}

${ }^{1}$ Treatments were $0,1.3,2.7$, and $3.3 \%$ coconut oil (CNO) in total dietary DM.

${ }^{2}$ Corn silage contained 28.1\% DM (as-fed basis), and 95.6\% OM, 46.9\% NDF, $9.2 \%$ indigestible NDF, $22.1 \%$ starch, $5.8 \%$ ether extract (EE), and $8.3 \% \mathrm{CP}$, DM basis.

${ }^{3}$ Alfalfa haylage contained $36.9 \%$ DM (as-fed basis), and $90.6 \% \mathrm{OM}, 45.2 \%$ NDF, $23.4 \%$ indigestible NDF, $0.9 \%$ starch, $6.2 \% \mathrm{EE}$, and $18.9 \% \mathrm{CP}$, DM basis.

${ }^{4}$ Grass silage contained $31.2 \%$ DM (as-fed basis), and 90.5\% OM, 59.7\% NDF, $15.7 \%$ indigestible NDF, $0.4 \%$ starch, $6.2 \% \mathrm{EE}$, and $12.7 \% \mathrm{CP}, \mathrm{DM}$ basis.

${ }^{5}$ SoyPlus (West Central Cooperative, Ralston, IA).

${ }^{6}$ Mineral-vitamin mix contained $43.1 \%$ limestone, $31.3 \%$ sodium bicarbonate, $9.7 \%$ magnesium sulfate, $8.1 \%$ sodium chloride, $3.0 \%$ trace minerals (contained $11.6 \% \mathrm{Ca}, 9.1 \% \mathrm{P}, 5.0 \% \mathrm{Fe}, 4.0 \% \mathrm{Mn}, 4.0 \% \mathrm{Zn}, 1.0 \% \mathrm{Cu}, 600$ $\mathrm{mg}$ of $\mathrm{I} / \mathrm{kg}, 300 \mathrm{mg}$ of Se $/ \mathrm{kg}$, and $200 \mathrm{mg}$ of $\mathrm{Co} / \mathrm{kg}), 2.5 \%$ biotin $(1.4 \mathrm{~g} / \mathrm{kg}), 0.6 \%$ Se-yeast, $57 \mathrm{kIU}$ of vitamin A per $\mathrm{kg}, 17 \mathrm{kIU}$ of vitamin D per $\mathrm{kg}$, and $0.8 \mathrm{kIU}$ of vitamin E per $\mathrm{kg}$, DM basis.

${ }^{7}$ Estimated using published values (NRC, 2001).

in a stationary tumble mixer in the order of low to greatest $\mathrm{CNO}$ concentrations. The tumble mixer was cleansed with corn silage following the preparation of the treatment with the greatest CNO concentration.

The experimental design was an incomplete (onehalf) $4 \times 4$ Latin square conducted in 2 periods. Eight primiparous and 16 multiparous Holstein cows from the Michigan State University Dairy Teaching and Research Center herd were fed a single basal adjustment diet without supplemental fat or monensin-Na for $21 \mathrm{~d}$ before initiation of the experiment. Primiparous cows and the 4 smallest secundiparous cows were assigned to block 1 (116 $\pm 30,85$ to 178 DIM; mean \pm SD, range), and the other 12 multiparous cows to block $2(129 \pm 15,107$ to $149 \mathrm{DIM})$. The 24 cows were arranged in 2 complete blocks. Within each block, cows were randomly assigned to 1 of 12 possible 2-treatment sequences for the 2 periods. Therefore, each possible treatment sequence occurred exactly once in each block. Total period length was $35( \pm 1)$ d. Cows were adapted to their respective dietary treatment for 21 $\mathrm{d}$ in a tie-stall barn, and then moved to individual, environmentally controlled rooms (described later) at the Animal Air Quality Research Facilities (Michigan State University). Days 22 to 28 were for adaptation to rooms and d 29 through 35 for all sampling and data collection. Cows in block 1 stayed in their individual, environmentally controlled rooms for the entire $35-\mathrm{d}$ first period to assess responses during the habituation to dietary treatment. Originally, the highest CNO treatment concentration was $4.0 \%$; however, the DMI of cows fed $4.0 \%$ CNO decreased precipitously and markedly by d 2 and remained depressed. Therefore, cows in block 1 that had been receiving the $4.0 \%$ CNO diet were removed from the experiment after $10 \mathrm{~d}$ and replaced with 3 different cows that had been adapted 
Table 2. Fatty acid profile of coconut oil (CNO) and experimental diets

\begin{tabular}{|c|c|c|c|c|c|}
\hline \multirow[b]{2}{*}{$\mathrm{FA}, \mathrm{g} / 100 \mathrm{~g}$ of $\mathrm{FA}$} & \multirow{2}{*}{$\frac{\text { Fat source }}{\mathrm{CNO}}$} & \multicolumn{4}{|c|}{ Treatment diet ${ }^{1}$} \\
\hline & & $\mathrm{CNO} 0$ & CNO1.3 & CNO2.7 & CNO3.3 \\
\hline $6: 0$ & 0.8 & - & - & - & - \\
\hline $8: 0$ & 9.1 & - & 1.1 & 2.0 & 2.4 \\
\hline 10:0 & 6.7 & - & 1.1 & 2.0 & 2.3 \\
\hline $12: 0$ & 40.8 & 0.2 & 7.6 & 12.0 & 11.7 \\
\hline $14: 0$ & 19.5 & 0.2 & 4.7 & 8.0 & 9.2 \\
\hline $16: 0$ & 9.8 & 14.5 & 12.8 & 13.0 & 13.7 \\
\hline 18:0 & 3.3 & 3.3 & 3.2 & 3.6 & 3.8 \\
\hline $18: 1$, cis & 6.9 & 23.1 & 19.3 & 17.6 & 18.0 \\
\hline 18:2, cis-9, cis- 12 & 1.7 & 44.0 & 40.7 & 34.2 & 31.7 \\
\hline $18: 3$ & 0.1 & 7.2 & 5.9 & 5.0 & 4.6 \\
\hline $\mathrm{VLCF}^{2}$ & 0.3 & 1.9 & 1.3 & 0.8 & 0.8 \\
\hline Others $^{3}$ & 0.9 & 5.2 & 2.1 & 1.8 & 1.7 \\
\hline SFA & 90.1 & 19.5 & 31.3 & 41.2 & 43.6 \\
\hline $\mathrm{MCFA}^{4}$ & 57.4 & 0.2 & 9.8 & 16.0 & 16.4 \\
\hline$c i s-\mathrm{FA}^{5}$ & 9.2 & 75.7 & 66.7 & 57.2 & 54.8 \\
\hline
\end{tabular}

${ }^{1}$ Treatments were $0,1.3,2.7$, and $3.3 \%$ CNO in total dietary DM.

${ }^{2} \mathrm{VLCF}=$ total very long-chain FA $(\geq 20 \mathrm{C})$.

${ }^{3}$ Others $=$ FA not listed and FA not identified.

${ }^{4} \mathrm{MCFA}=$ total medium-chain $\mathrm{FA}(6 \mathrm{C} \leq \mathrm{MCFA} \leq 12 \mathrm{C})$.

${ }^{5}$ cis-FA $=$ total $\mathrm{FA}$ with a cis configuration.

to CNO0, CNO1.3, or CNO2.7 on d 12. These replacement cows received CNO3.3. Further discussion about the habituation to CNO feeding ( $\mathrm{d}-1$ to $\mathrm{d} 34$ in block 1 , period 1) will be presented in a different paper.

Cows were kept in tie-stalls while in their individual environmentally controlled rooms with artificial lighting between 0400 and $2000 \mathrm{~h}$. Those tie-stalls were designed to the same dimensions as the tie-stalls at the Michigan State University Dairy Teaching and Research Center. Cows were milked in place between 0430 and $0630 \mathrm{~h}$, and between 1630 and $1830 \mathrm{~h}$. They were offered about $40 \%$ of their TMR at morning milking and $60 \%$ at the afternoon milking to maintain at least $10 \%$ refusal at the end of each shift. Orts were collected and recorded at each milking and ad libitum feed intake was computed. Manure was collected in a pan behind each tie-stall, and manure above a depth of approximately $5 \mathrm{~cm}$ was removed daily as part of the morning chores.

\section{Data and Sample Collections and Analyses}

Environmentally controlled rooms were kept continuously under positive air pressure. Air flow in and out of each room, and temperature and relative humidity of outlet air from each room were recorded continuously using a pressure transducer (Setra Model 239; Setra Systems Inc., Boxborough, MA) and a temperature and relative humidity probe (CS500; Campbell Scientific Inc., Logan, UT), respectively (Li et al., 2011). Air flow into the rooms was regulated continuously to control room temperature within a range of 12 to $18^{\circ} \mathrm{C}$; air flux always exceeded $1.7 \mathrm{~m}^{3} /$ min or 4 complete air changes per hour in each room. Concentrations of $\mathrm{CH}_{4}$ in air were analyzed once per minute with an Innova Model 1412 photoacoustic analyzer (LumaSense Technologies A/S, Ballerup, DK) that was calibrated once weekly with gas standards of known $\mathrm{CH}_{4}$ concentrations. Measurements of $\mathrm{CH}_{4}$ concentrations were obtained from an incoming air stream and out-flowing air streams from each room continuously for 5.5 min once every 3 h. Prior to sampling, air hoses supplying the analyzer were purged for 18.5 (incoming air to ventilate rooms) and 7.5 min (out-flowing air from each room). Thus, 5 to 6 data points of $\mathrm{CH}_{4}$ concentrations were available from each room 8 times per day. Each room was closed for at least $1 \mathrm{~h}$ before sampling of air for $\mathrm{CH}_{4}$ analysis. Incoming air data were lost for d 34 and 35 for the second period of block 2; thus, data for d 27 to 33 were used for analysis for that block-period. Additionally, air exchanges were occasionally below $3 / \mathrm{h}$ due to problems with the air heating unit during cold weather; corresponding $\mathrm{CH}_{4}$ data were removed from the data set. Overall, usable $\mathrm{CH}_{4}$ data were obtained for $85 \%$ of all possible 3 -h sampling periods. Original, individual $\mathrm{CH}_{4}$ measurements in the top and bottom fifth percentile of each treatment in each block-period were inspected. Individual readings were defined as outliers if they differed from the mean of the respective 3 -h sampling period and room by more than 3 standard deviations. A total of $1.1 \%$ of original measurements was rejected.

Concentrations of $\mathrm{CH}_{4}$ of the incoming air for each room at the time of sampling were calculated from 2 consecutive (separated by $3 \mathrm{~h}$ ) measurements of incom- 
ing air. The mean incoming $\mathrm{CH}_{4}$ concentration was weighted by the respective time lag between incoming air and room measurements. Methane concentrations were converted to standard temperature and pressure, and $\mathrm{CH}_{4}$ emission rates were calculated by mass balance of $\mathrm{CH}_{4}$ in the incoming and out-flowing air ( $\mathrm{Li}$ et al., 2011). The $\mathrm{CH}_{4}$ emission rates were then averaged for each 3-h period in each room and day within each block-period. All $\mathrm{CH}_{4}$ emissions were assumed to be of enteric origin.

Individual cow MY, feed offered, and orts removed were recorded at each milking. Milk was sampled $2 \mathrm{~d}$ per week and analyzed for concentrations of fat, true protein, lactose, and non-fat solids by mid-infrared spectroscopy (AOAC, 1990), and for urea-N by modified Berthelot reaction (ChemSpec 150 Analyzer; Bentley Instruments Inc., Chaska, MN) by Michigan DHIA (East Lansing). Solids-corrected MY was calculated according to Tyrrell and Reid (1965) with a 0.95 adjustment factor for milk true protein (Verdi et al., 1987). One additional milk sample for each cow was frozen at $-20^{\circ} \mathrm{C}$ and later pooled by milk fat yield for each cow within each period-block. Milk fat was extracted (Sukhija and Palmquist, 1988) and prepared for determination of milk FA profile as described by Bradford and Allen (2004). Individual FA were determined by gas chromatography (model 8500; Perkin-Elmer Corp., Norwalk, CT) at the Diagnostic Center for Population Animal Health (East Lansing, MI) with the following specifications: SP-2560 capillary column $(100 \mathrm{~m} \times 0.20$ $\mathrm{mm}$ i.d. with $0.02-\mu \mathrm{m}$ film thickness; Supelco Inc., Bellefonte, PA); oven temperature at $70^{\circ} \mathrm{C}$ for $4 \mathrm{~min}$, then increased by $13^{\circ} \mathrm{C} / \mathrm{min}$ to $175^{\circ} \mathrm{C}$ and sustained for $27 \mathrm{~min}$ before being increased again at $4^{\circ} \mathrm{C} / \mathrm{min}$ to $215^{\circ} \mathrm{C}$ and sustained for $31 \mathrm{~min}$; and $\mathrm{H}$ flow of $20 \mathrm{~cm} / \mathrm{s}$.

Forage samples were dried to a constant weight in a forced-air oven $\left(60^{\circ} \mathrm{C}\right)$ to determine $\mathrm{DM}$ content; diets were adjusted twice weekly to maintain the same proportions of all dietary ingredients on a DM basis. All forages and concentrate premixes were sampled twice weekly and frozen. Fecal samples were collected per rectum immediately after each milking on d 32 through 35. Upon thawing, feed and fecal samples were subsampled, lyophilized (TriPhilizer MP; FTS Systems Inc., Stone Ridge, NY), and ground in a Wiley mill (1-mm screen; Arthur H. Thomas Co., Philadelphia, PA). Feed samples were composited by ingredient for each block-period, and fecal samples were combined by individual cow for each block-period based on DM content $\left(105^{\circ} \mathrm{C}\right)$. Ash concentrations of feed and fecal samples were obtained by 5 -h oxidation at $500^{\circ} \mathrm{C}$ in a muffle furnace. Organic matter was the difference between DM and ash contents. Concentrations of CP and NDF were analyzed (Hach et al., 1987; Van Soest et al., 1991, method A). Starch concentrations in feed and fecal samples were assayed by gelatinizing samples with $\mathrm{NaOH}$ and subsequently measuring glucose concentration enzymatically (Karkalas, 1985; Glucose kit \#510; Sigma Chemical Co., St. Louis, MO) using a microplate absorbance reader (SpectraMax 190; Molecular Devices Corp., Sunnyvale, CA). Ether extract (EE) was analyzed according to the AOAC (1990) method. Fatty acids were extracted from forage and concentrate samples and from pooled fecal samples (Sukhija and Palmquist, 1988) and determined by gas chromatography as described above. Indigestible NDF (iNDF) determined as ash-free NDF residue after 240-h in vitro fermentation was used as marker to estimate apparent nutrient digestibilities (Goering and Van Soest, 1970). In vitro fermentation was with ruminal fluids from 2 nonpregnant, nonlactating cows fed a grass hay diet ad libitum. The digestibility coefficient (A) of a specific nutrient was calculated based on fecal concentration (B) and daily intake (C) of that nutrient:

$$
\mathrm{A}=1-\mathrm{iNDFI} \times[\text { fecal iNDF }]^{-1} \times[\mathrm{B}] \times \mathrm{C}^{-1},
$$

where iNDFI is the daily intake of iNDF. Potentially digestible NDF (pdNDF) was calculated as the difference between NDF and iNDF. Gross energy (GE) was assayed by bomb calorimetry (Model 1241; Parr Instrument Inc., Moline, IL). Metabolizable energy and $\mathrm{NE}_{\mathrm{L}}$ were calculated according to NRC (2001) based on digestible energy (DE) and with a multiple of intake of 3 times maintenance for $\mathrm{NE}_{\mathrm{L}}$ using the following equations:

$$
\begin{gathered}
\mathrm{ME}_{(\text {intake) }}=\left(1.01 \times \mathrm{DE}_{(\text {intake) }}-0.45\right) \\
+0.0046 \times([\mathrm{EE}]-3) ; \\
\mathrm{NE}_{\mathrm{L}(\text { intake) }}=0.703 \times \mathrm{ME}_{(\text {intake })}-0.19 \\
+\left(0.097 \times \mathrm{ME}_{(\text {intake) }}+0.19\right) / 97 \times([\mathrm{EE}]-3) ; \\
\mathrm{NE}_{\mathrm{L}(\text { milk })}(\mathrm{Mcal} / \mathrm{d})=\mathrm{MY}(\mathrm{kg}) \times(0.0929 \\
\times[\text { milk fat }]+0.0563 \times[\text { milk true protein }] \\
+0.0395 \times[\text { milk lactose }]) .
\end{gathered}
$$

\section{Statistical Analyses}

Statistical analyses were conducted using linear mixed effects models (PROC MIXED, SAS 9.1.3; SAS Institute Inc., Cary, NC). The final model to analyze effect of dietary $\mathrm{CNO}$ on $\mathrm{eCH}_{4}$ emissions included the fixed effects of dietary treatment, block, time of day, period within block, and the interactions of treatment 
by block, time of day by block, treatment by time of day, and treatment by time of day by block. The experimental design accounted for carryover effects. However, results were only adjusted for carryover effect in cases where carryover effects were found to be significant $(P<0.01)$. Random effects in the model were cow nested within block; dietary treatment by period by cow within block to identify the experimental unit for dietary treatment; time of day by dietary treatment by period by cow by block to identify the cow assigned to dietary treatment as the blocking factor for time of day and to account for replication related to day. Kenward-Roger's method was used to estimate degrees of freedom.

Data for MY, yields and concentrations of milk components, nutrient intakes, and digestibilities were pooled for each cow by block-period and analyzed with a simplified model without the effect of time of day. Effects of dietary concentration of $\mathrm{CNO}$ were determined using linear and quadratic orthogonal contrasts. Significance was declared at $P<0.05$ and marginal significance at $P<0.10$ for main fixed effects and $P$ $<0.15$ for interactions. Linear or quadratic effects are denoted as $\boldsymbol{P}_{\mathbf{L}}$ or $\boldsymbol{P}_{\mathbf{Q}}$, respectively. Data of $\mathrm{eCH}_{4}$ were log-transformed before analysis to achieve normal distribution of the residuals.

\section{RESULTS}

\section{Enteric $\mathrm{CH}_{4}$ Emissions and DMI}

Cows fed the dietary control treatment (CNO0) emitted an estimated $464 \mathrm{~g}$ of $\mathrm{eCH}_{4} / \mathrm{cow}$ per day (Table 3). Dietary concentration of CNO reduced $\mathrm{eCH}_{4}$ emissions quadratically $\left(P_{\mathrm{L}, \mathrm{Q}}<0.01\right)$. Feeding $1.3 \% \mathrm{CNO}, \mathrm{DM}$ basis, lowered $\mathrm{eCH}_{4}$ emissions only slightly $(449 \mathrm{~g} / \mathrm{cow}$ per day), whereas feeding twice and 2.5-times as much CNO (CNO2.7 and CNO3.3, respectively) lowered $\mathrm{eCH}_{4}$ emissions to an estimated 291 and $253 \mathrm{~g} /$ cow per day, respectively. An interaction of time of day and dietary $\mathrm{CNO}$ concentration affected rates of $\mathrm{eCH}_{4}$ emissions (Figure 1; $P<0.01$ ). This interaction was based on cows fed CNO3.3 having lower emission rates prefeeding than CNO2.7-fed cows; such difference on $\mathrm{eCH}_{4}$ emissions was not apparent post-feeding (Figure 1). Overall, rates of $\mathrm{eCH}_{4}$ emissions were highest after the main feeding in the afternoon, but also increased after the morning feeding $(P<0.001)$. Methane emissions in the present experiment are presumably from enteric origin, because $\mathrm{CH}_{4}$ emissions from fresh manure are minute (Sun et al., 2008), and most of the manure was removed daily.

Control cows consumed $22.9 \mathrm{~kg}$ of DM/d (Table 3). Increased dietary CNO concentration decreased DMI linearly $\left(P_{\mathrm{L}}<0.001\right)$, but also decreased $\mathrm{eCH}_{4}$ emitted per unit of DMI $\left(P_{\mathrm{O}}<0.04\right.$; Table 3). Enteric $\mathrm{CH}_{4}$ emissions per unit of DMI were similar for cows fed CNO0 and CNO1.3 (21.1 and $21.3 \mathrm{~g} / \mathrm{kg}$, respectively), but were lower for cows fed CNO2.7 $(17.4 \mathrm{~g} / \mathrm{kg})$ or CNO3.3 $(16.7 \mathrm{~g} / \mathrm{kg})$.

\section{MY and Components}

The CNO1.3 treatment resulted in the greatest yields of milk $\left(P_{\mathrm{Q}}<0.07\right)$, SCM $\left(P_{\mathrm{Q}}<0.01\right)$, and milk fat $\left(P_{\mathrm{Q}}<0.001\right)$, whereas CNO2.7 and CNO3.3 depressed those yields (Table 3 ). Control cows yielded milk with $3.47 \%$ fat. Cows fed CNO1.3 had the highest milk fat concentration (3.66\%), but greater dietary CNO concentrations depressed milk fat concentration severely $\left(P_{\mathrm{Q}}\right.$ $<0.001)$. Increased concentration of $\mathrm{CNO}$ decreased concentrations of milk protein $\left(P_{\mathrm{L}}<0.03\right)$, lactose, and non-fat solids $\left(P_{\mathrm{L}}<0.001\right)$, but increased MUN $\left(P_{\mathrm{L}}<\right.$ 0.001). Cows fed CNO2.7 and CNO3.3 produced approximately $89 \%$ of the MY of CNO0-fed cows, but only approximately $71 \%$ of the milk fat yield. As a result, CNO2.7 and CNO3.3 decreased SCMY by $21 \%$ compared with CNO0. In contrast, CNO1.3-fed cows produced approximately $4 \%$ more SCMY based on an $8 \%$ increase in milk fat yield compared with CNO0. Overall, $\mathrm{eCH}_{4}$ emitted per unit of SCMY decreased linearly as dietary CNO concentrations increased $\left(P_{\mathrm{L}}\right.$ $<0.001)$.

\section{Nutrient Intakes and Apparent Digestibilities}

Increased dietary $\mathrm{CNO}$ concentration decreased intakes of OM, NDF, pdNDF, CP, and starch $\left(P_{\mathrm{L}}<0.001\right)$. However, intakes of EE increased as dietary treatments contained increased CNO concentrations $\left(P_{\mathrm{L}}<0.01\right)$. Dietary CNO concentration decreased amounts of DM, $\mathrm{OM}, \mathrm{NDF}, \mathrm{CP}$, and starch apparently digested in the total tract $\left(P_{\mathrm{L}}<0.001 ; P_{\mathrm{Q}}<0.04\right)$ with greater reductions as CNO concentration increased (Table 4). Increased dietary $\mathrm{CNO}$ concentration depressed apparent total tract digestibilities of DM and OM $\left(P_{\mathrm{L}}<0.001\right)$. This was likely influenced heavily by the decrease in NDF digestibility $\left(P_{\mathrm{L}}<0.001 ; P_{\mathrm{Q}}<0.04\right)$ as we had no evidence that $\mathrm{CNO}$ concentration had any effect in apparent digestibility of $\mathrm{CP}$; yet, $\mathrm{CNO}$ increased apparent starch digestibility $\left(P_{\mathrm{L}}<0.001\right)$. Treatment CNO3.3 depressed NDF digestibility by $38 \%$ compared with CNO0. In contrast, dietary CNO concentration increased the amount of EE apparently digested in the total tract $\left(P_{\mathrm{L}}<0.001 ; P_{\mathrm{Q}}<0.02\right)$ and the respective coefficients of digestibility $\left(P_{\mathrm{L}}<0.001\right)$. Overall, $\mathrm{eCH}_{4}$ emitted per unit of DM apparently digested in the total tract decreased with increasing dietary $\mathrm{CNO}$ 


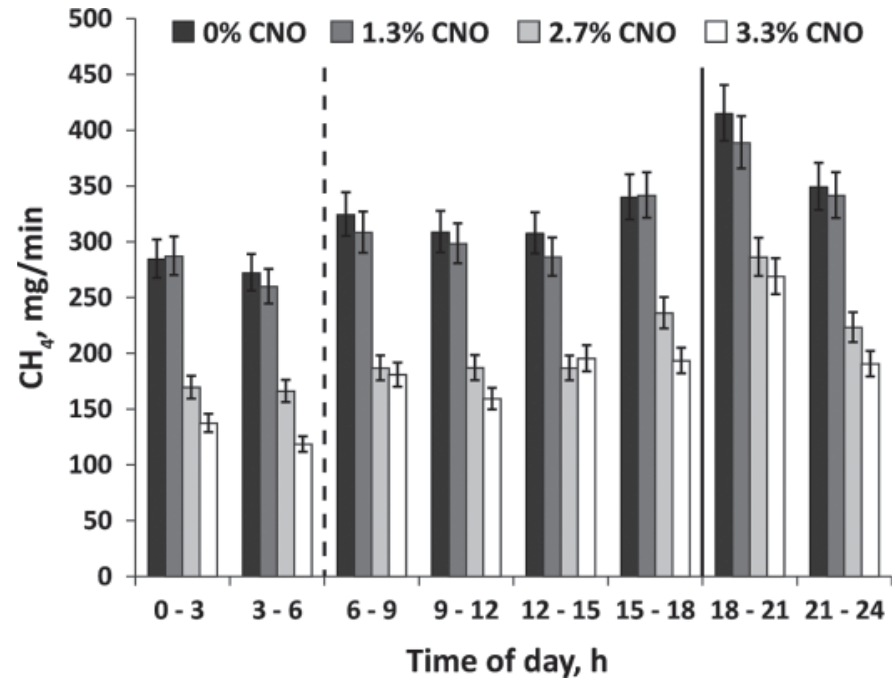

Figure 1. Variation in enteric methane $\left(\mathrm{CH}_{4}\right)$ emissions from lactating dairy cows throughout the day based on measures taken every $3 \mathrm{~h}$ relative to feeding after adaptation to diets with different concentrations of coconut oil (CNO). Gas emissions are estimated from 4- to 5-min readings during each 3 -h period. Cows were fed ad libitum after the 3 to $6 \mathrm{~h}$ and the 15 to $18 \mathrm{~h}$ gas readings, but consumed the majority of their ration ( 55 to $58 \%$ of total daily DMI, SEM: \pm 1.4 , no effect of treatment) between afternoon and morning feedings. Columns immediately to the right of dashed line (morning feeding) and solid line (afternoon feeding) represent the first post-feeding measurement. Interaction of treatment and time of day $(P<0.001)$. concentrations $\left(P_{\mathrm{L}}<0.001\right)$. In contrast, $\mathrm{eCH}_{4}$ emitted per unit of NDF digested in the total tract increased with dietary $\mathrm{CNO}$ concentration $\left(P_{\mathrm{L}}<0.001\right)$.

\section{Energetics}

Increased concentrations of $\mathrm{CNO}$ decreased the intake of gross, digestible, and calculated net energy $\left(P_{\mathrm{Q}}<0.01\right)$, with greater reductions occurring with CNO2.7 and CNO3.3 than with CNO1.3 (Table 5). Furthermore, CNO2.7 and CNO3.3 decreased milk energy output by 19 and $23 \%$ compared with CNO0, respectively; whereas CNO1.3 showed the greatest milk energy output $\left(P_{\mathrm{L}}<0.001 ; P_{Q}<0.01\right)$; yet, $\mathrm{CNO}$ concentration also decreased GE emitted in $\mathrm{eCH}_{4}\left(P_{\mathrm{L}}\right.$ $\left.<0.001 ; P_{\mathrm{Q}}<0.01\right)$. As a result, increased CNO concentration decreased $\mathrm{eCH}_{4}$ emitted as a proportion of energy intake and milk energy output $\left(P_{\mathrm{L}}<0.001\right)$. Increased CNO concentration improved the conversion of DE into milk energy $\left(P_{\mathrm{L}}<0.01\right)$. The energy results for CNO2.7 and CNO3.3 have to be evaluated with caution because the corresponding GE value was lower than expected (Table 1). It is likely that CNO of the concentrate premix stuck to the equipment during preparation of feed samples, as we have speculated elsewhere

Table 3. Effects of dietary concentration of coconut oil $(\mathrm{CNO})$ on enteric $\mathrm{CH}_{4}$ emissions and lactational performance

\begin{tabular}{|c|c|c|c|c|c|c|c|}
\hline Item & \multicolumn{4}{|c|}{ Treatment LSM estimates $^{1}$} & $\mathrm{SE}$ & \multicolumn{2}{|c|}{$P$-value ${ }^{2}$} \\
\hline $\mathrm{CH}_{4}, \mathrm{~g} / \mathrm{d}$ & 464 & 449 & 291 & 253 & $-^{3}$ & $<0.001$ & 0.01 \\
\hline $\mathrm{CH}_{4} / \mathrm{DMI}, \mathrm{g} / \mathrm{kg}$ & 21.1 & 21.3 & 17.4 & 16.7 & 0.60 & $<0.001$ & 0.04 \\
\hline \multicolumn{8}{|l|}{ Yield, $\mathrm{kg} / \mathrm{d}$} \\
\hline Milk (7-d collection $)^{4}$ & 37.1 & 37.5 & 33.7 & 32.4 & 1.03 & $<0.001$ & 0.07 \\
\hline Milk fat & 1.27 & 1.37 & 0.94 & 0.86 & 0.050 & $<0.001$ & 0.001 \\
\hline Milk protein & 1.04 & 1.05 & 0.91 & 0.89 & 0.033 & $<0.001$ & 0.12 \\
\hline Milk lactose & 1.82 & 1.84 & 1.60 & 1.52 & 0.055 & $<0.001$ & 0.04 \\
\hline Milk SNF & 2.68 & 2.67 & 2.35 & 2.27 & 0.089 & $<0.001$ & NS \\
\hline \multicolumn{8}{|l|}{ Milk composition, \% } \\
\hline Milk fat & 3.47 & 3.66 & 2.79 & 2.67 & 0.093 & $<0.001$ & 0.001 \\
\hline
\end{tabular}

${ }^{1}$ Treatments were $0,1.3,2.7$, and $3.3 \%$ CNO in total dietary DM.

${ }^{2} P$-values correspond to orthogonal contrasts of linear and quadratic (Quad.) effect of dietary concentration of CNO. NS: $P>0.20$.

${ }^{3}$ Log-transformed for analysis. Least squares means back-transformed; standard error of the means of transformed results $=0.047 ; 95 \%$ confidence intervals of back-transformed least squares means were CNO0: 422 to $511 \mathrm{~g} / \mathrm{d}$; CNO1.3: 408 to $493 \mathrm{~g} / \mathrm{d}$; CNO2.7: 264 to $320 \mathrm{~g} / \mathrm{d}$; and CNO3.3: 230 to $278 \mathrm{~g} / \mathrm{d}$.

${ }^{4}$ Milk yield from 7-d collection period (d 29 to 35 of trial).

${ }^{5}$ Milk yield from 2-d subperiod in which milk composition was analyzed.

${ }^{6} \mathrm{SCMY}=$ solids-corrected milk yield $(\mathrm{MY}):\{\mathrm{MY} \times([$ milk fat $] \times 41.63+[$ milk true protein $] / 0.95 \times 24.13+[$ milk lactose $] \times 21.6)-11.72\} / 340$ (Tyrrell and Reid, 1965). Conversion factor (0.95) for [milk true protein] to [milk protein] based on Verdi et al. (1987). 
Table 4. Effects of dietary concentration of coconut oil (CNO) on DMI and nutrient digestibilities

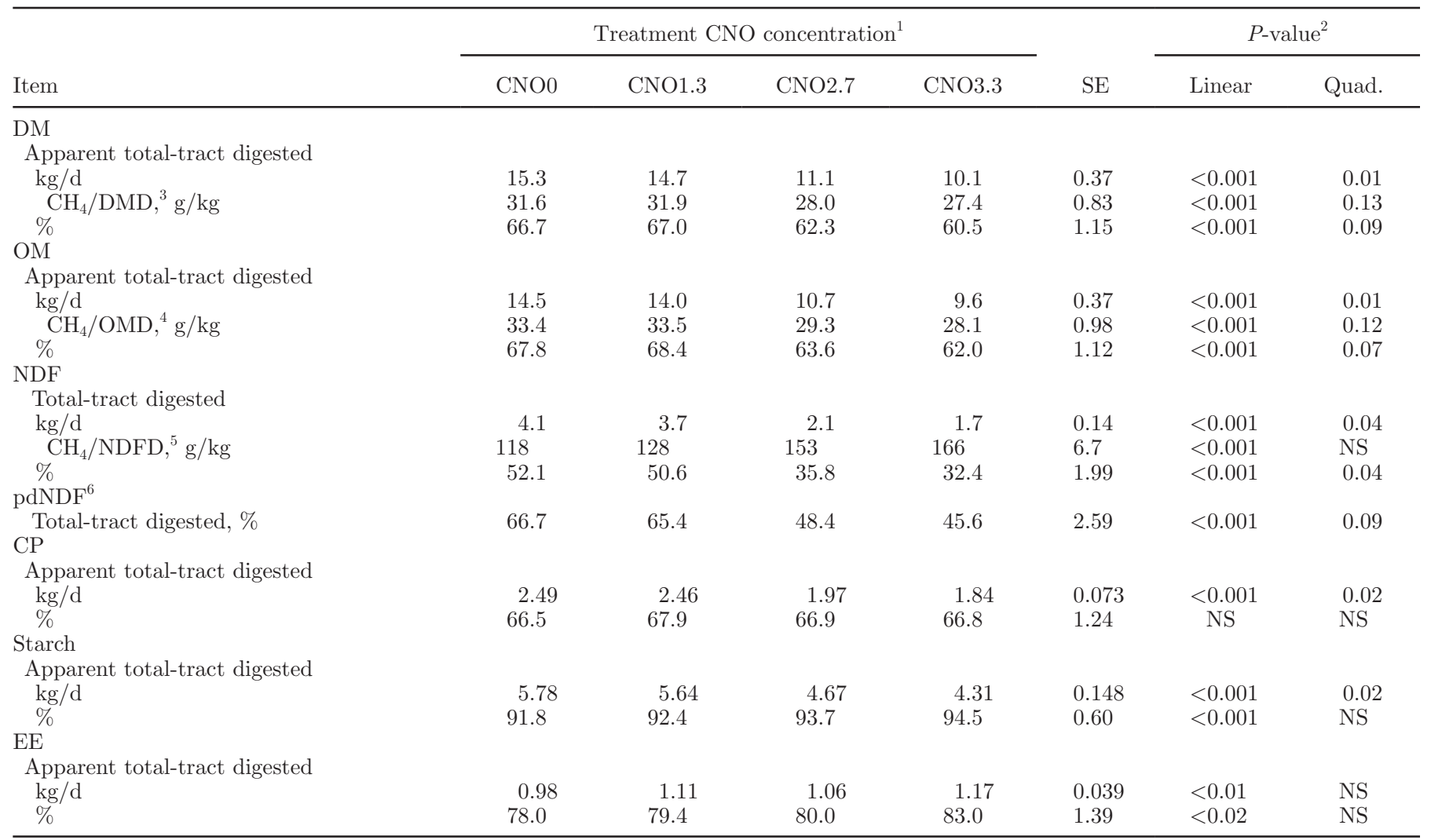

${ }^{1}$ Treatments were $0,1.3,2.7$, and $3.3 \%$ CNO in total dietary DM.

${ }^{2} P$-values correspond to orthogonal contrasts of linear and quadratic (Quad.) effects of dietary concentration of CNO. NS: $P>0.20$.

${ }^{3}$ DMD: total-tract apparently digested DM.

${ }^{4} \mathrm{OMD}$ : total-tract apparently digested OM.

${ }^{5}$ NDFD: total-tract apparently digested NDF.

${ }^{6} \mathrm{pdNDF}=$ potentially digestible NDF.

(Hollmann and Beede, 2012). Nonetheless, we would expect the nature of the inference to remain unchanged if the increase in dietary GE density between $\mathrm{CNO} 0$ and CNO1.3 is extrapolated to CNO2.7 (4.53 Mcal $/ \mathrm{kg})$ and CNO3.3 (4.61 Mcal $/ \mathrm{kg})$.

\section{Apparent Digestibility and Milk Output of FA}

No $\mathrm{C}_{8}$ and $\mathrm{C}_{10}$ FA and only trace amounts of $\mathrm{C}_{12}$ and $\mathrm{C}_{14}$ were identified in $\mathrm{CNO}$, but increased dietary concentrations of $\mathrm{CNO}$ resulted in increased intakes of those FA in the remaining treatments (Table 6). Intake of $\mathrm{C}_{16} \mathrm{FA}$ increased in a diminishing fashion with increased CNO concentration $\left(P_{\mathrm{L}}<0.001 ; P_{Q}<0.01\right)$. Intakes of $\mathrm{C}_{18} \mathrm{FA}$ were greatest for cows fed CNO1.3 $(767 \mathrm{~g} / \mathrm{d})$ and $\mathrm{CNO} 2.7\left(719 \mathrm{~g} / \mathrm{d} ; P_{\mathrm{L}, \mathrm{Q}}<0.001\right)$. No $\mathrm{C}_{8}$ and $\mathrm{C}_{10} \mathrm{FA}$ were detected in feces; thus, their apparent total tract digestibilities were considered to be complete. As FA chain length increased, apparent digestibility decreased from an estimated $97 \%$ for $\mathrm{C}_{12} \mathrm{FA}$ to approximately 72 and $76 \%$ for $\mathrm{C}_{16} \mathrm{FA}$ and $\mathrm{C}_{18} \mathrm{FA}$, respectively (Table 6).

Dietary CNO concentrations of 2.7 and $3.3 \%$ decreased concentrations of FA shorter than $\mathrm{C}_{12}\left(P_{\mathrm{L}}<\right.$ 0.001); however, dietary $\mathrm{CNO}$ concentration increased milk fat concentrations of $\mathrm{C}_{12}$ and $\mathrm{C}_{14} \mathrm{FA}\left(P_{\mathrm{L}}<0.001\right.$; Table 7$)$. This increase was compensated by a decrease in concentrations of $\mathrm{C}_{16}$ and $\mathrm{C}_{18}$ milk FA. Dietary $\mathrm{CNO}$ concentration increased milk fat concentrations of trans-FA $\left(P_{\mathrm{L}}<0.001\right)$ and the milk fat-depressing $\mathrm{C}_{18: 2}$ trans-10, cis-12 $\left(P_{\mathrm{L}}<0.01\right)$. These differences in FA concentrations in milk fat caused changes in yields of milk FA (Figure 2; $P<0.001$ ). Cows fed CNO2.7 and CNO3.3 yielded approximately $44 \%$ less $\mathrm{FA}$ shorter than $\mathrm{C}_{12}$, $34 \%$ less $\mathrm{C}_{16} \mathrm{FA}$, and $30 \%$ less $\mathrm{FA}$ longer than $\mathrm{C}_{16}$ than CNO0-fed cows. The increase in milk fat yield with dietary CNO1.3 treatment was due to greater yields of milk FA with a chain length from $\mathrm{C}_{12}$ to $\mathrm{C}_{16}$. However, yields of the sum of $\mathrm{C}_{12}$ to $\mathrm{C}_{14}$ were similar between CNO0, CNO2.7, and CNO3.3 treatments. 
Table 5. Effects of dietary concentration of coconut oil (CNO) on energy efficiency

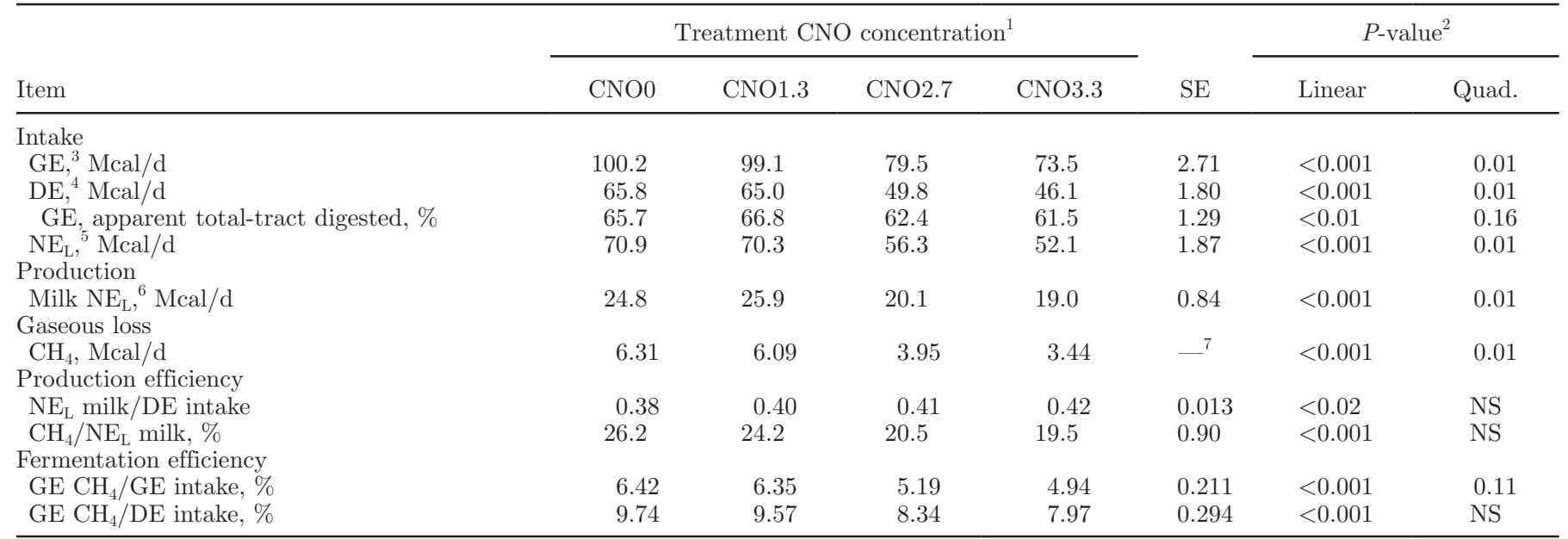

${ }^{1}$ Treatments were $0,1.3,2.7$, and $3.3 \%$ CNO in total dietary DM.

${ }^{2} P$-values correspond to orthogonal contrasts of linear and quadratic (Quad.) effect of dietary concentration of CNO. NS: $P>0.20$.

${ }^{3}$ Gross energy.

${ }^{4}$ Digestible energy

${ }^{5} \mathrm{NE}_{\mathrm{L}(\text { intake) }}=0.703 \times \mathrm{ME}_{\text {(intake) }}-0.19+\left(0.097 \times \mathrm{ME}_{\text {(intake) }}+0.19\right) / 97 \times([$ ether extract $]-3) ; \mathrm{ME}_{\text {(intake) }}=\left(1.01 \times \mathrm{DE}_{\text {(intake) }}-0.45\right)+0.0046 \times$ ([ether extract] - 3) (NRC, 2001).

${ }^{6} \mathrm{NE}_{\mathrm{L}(\text { milk })}(\mathrm{Mcal} / \mathrm{d})=$ milk yield $(\mathrm{kg}) \times(0.0929 \times[$ milk fat $]+0.0563 \times[$ milk true protein $]+0.0395 \times[$ milk lactose $])(\mathrm{NRC}, 2001)$.

${ }^{7} \mathrm{Log}$-transformed for analysis. Least squares means are back-transformed; standard error of the means of transformed data $=0.019 ; 95 \%$ confidence intervals of back-transformed least squares means were CNO0: 5.74 to $6.95 \mathrm{Mcal} / \mathrm{d}$; CNO1.3: 5.55 to $6.70 \mathrm{Mcal} / \mathrm{d}$; CNO2.7: 3.59 to 4.35 $\mathrm{Mcal} / \mathrm{d}$; and CNO3.3: 3.13 to $3.78 \mathrm{Mcal} / \mathrm{d}$.

\section{DISCUSSION}

\section{Methane Emissions and Lactational Responses}

Magnitude of $\mathrm{eCH}_{4}$ Emissions from the Control Diet. The high-producing dairy cows not treated with $\mathrm{CNO}$ emitted an estimated $464 \mathrm{~g}$ of $\mathrm{eCH}_{4} /$ cow daily in the current experiment (Table 3). This was slightly greater than the 390 to $450 \mathrm{~g}$ of $\mathrm{eCH}_{4} /$ cow per day range reported previously (Johnson et al., 2002), but lower than the 540 to $650 \mathrm{~g} / \mathrm{cow}$ per day range reported more recently (Aguerre et al., 2011). Type and dietary concentration of forage and DMI as a multiple of maintenance might help explain in part differences in $\mathrm{eCH}_{4}$ emissions among studies. Decreased NDF digestibility decreases $\mathrm{eCH}_{4}$ (Blaxter and Clapperton, 1965) and NDF in alfalfa is less digestible than NDF in corn silage. For example, $80 \%$ of corn silage NDF was pdNDF in the current experiment, but only $48 \%$ of alfalfa NDF was pdNDF. Presently, $74 \%$ of forage or $37 \%$ of dietary DM was corn silage.

Enteric $\mathrm{CH}_{4}$ Emissions and NDF Digestion. The decrease in $\mathrm{eCH}_{4}$ emissions at dietary $\mathrm{CNO}$ concentration of $2.7 \%$ or greater (Table 3 ) was consistent with previous reports in beef cattle (Jordan et al., 2006). Concomitant reductions in NDF intake and amount of total tract NDF digested (Table 4) may in part explain the decrease in $\mathrm{eCH}_{4}$ emissions. The present decrease in NDF digestion was consistent with other reports, where MCFA were fed (Külling et al., 2002; Jordan et al., 2006; Hollmann and Beede, 2012). Remarkably, CNO decreased NDF digestibility, although CNO depressed overall NDF intake and presumably increased ruminal retention time of NDF. Furthermore, CNO decreased NDF digestion in the total tract, even though a reduction in ruminal NDF digestibility can be compensated by increased NDF digestion in the hindgut (Sutton et al., 1983). Therefore, ruminal fermentation of NDF was presumably more severely depressed than suggested by the total tract digestibility coefficient for NDF. Hindgut fermentation accounted for 6 to $14 \%$ of total enteric methane production in sheep fed a forage diet (Immig, 1996). But, this likely depends on rate of passage through the hindgut and contents of the digesta entering the duodenum. Shifting NDF digestion from the rumen to the lower tract may reduce $\mathrm{eCH}_{4}$ emissions because acetogenesis is more competitive with methanogenesis in the hindgut (Immig, 1996). However, the capacity to digest NDF in the hindgut is limited (Sutton et al., 1983) and did not compensate for reduction in ruminal NDF digestion in MCFA treatment diets in the current and previous experiments (Külling et al., 2002; Jordan et al., 2006; Hollmann and Beede, 2012). Importantly, microbial proteins generated in the 
Table 6. Effects of dietary concentration of coconut oil (CNO) on intake and digestibility of FA by chain length

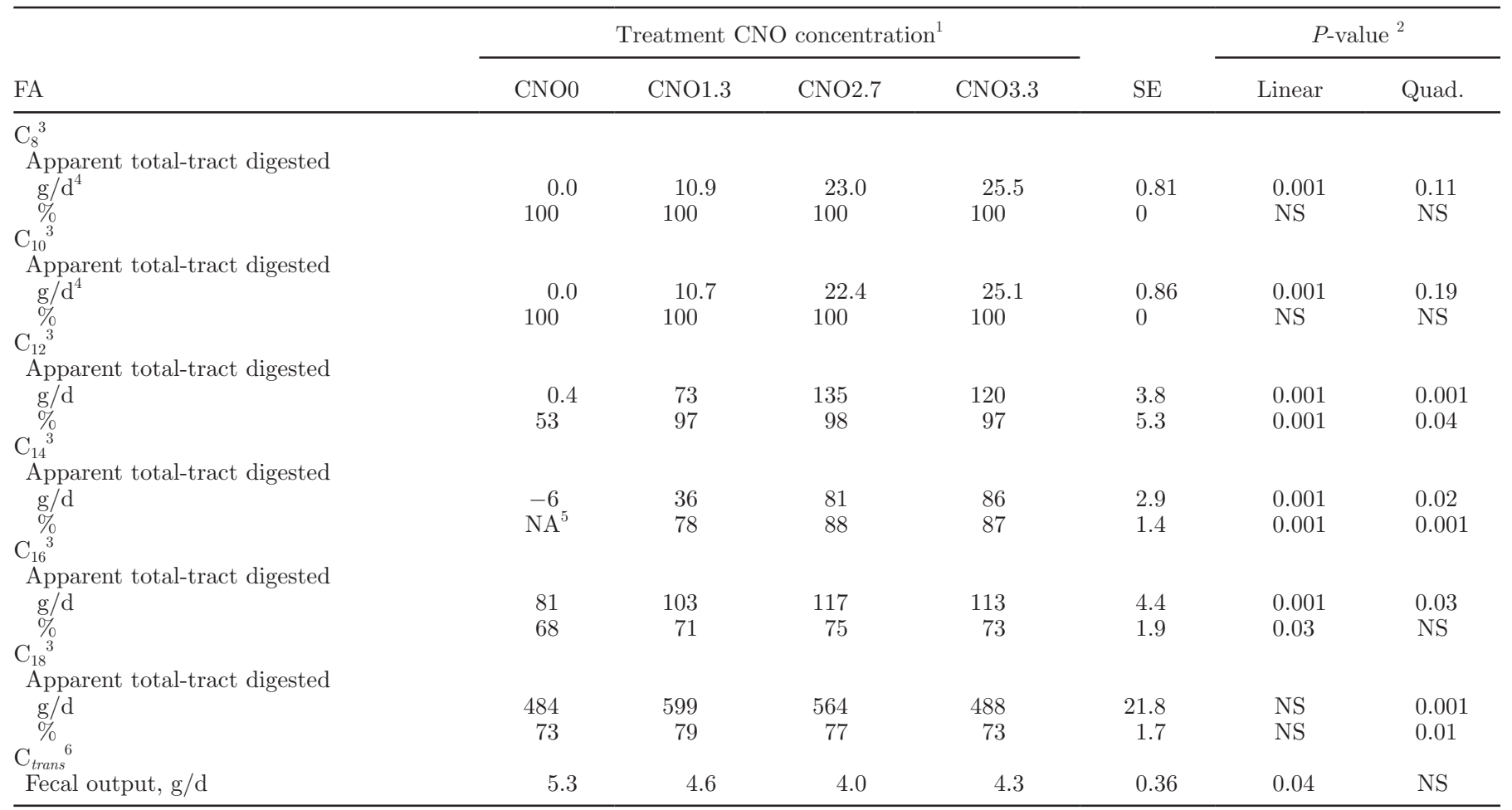

${ }^{1}$ Treatments were $0,1.3,2.7$, and $3.3 \%$ CNO in total dietary DM.

${ }^{2} P$-values correspond to orthogonal contrasts of linear and quadratic (Quad.) effect of dietary concentration of CNO. NS: $P>0.20$.

${ }^{3}$ Sum of all FA of this chain length.

${ }^{4}$ This FA was not detected in feces.

${ }^{5}$ Not available; apparent digestive tract release of $\mathrm{C} 14(P<0.06)$.

${ }^{6} \mathrm{Sum}$ of all FA of this configuration.

process of hindgut fermentation are largely unavailable to the host animal. Thus, transferring part of the NDF digestion to the lower digestive tract of ruminants to reduce $\mathrm{eCH}_{4}$ emissions also may decrease benefits of ruminal NDF digestion and microbial protein yields.

Often in research, MCFA are fed to mitigate methane emissions based on partial elimination of protozoa (Reveneau, 2008) and, either consequently or concurrently, methanogens from the rumen (Machmüller, 2006). Dietary CNO (Reveneau, 2008) and specifically $\mathrm{C}_{12: 0}$ and $\mathrm{C}_{10: 0}$ (Matsumoto et al., 1991) decrease the density of protozoa in ruminal contents. Protozoa are not necessarily needed to maintain ruminal NDF digestion. However, protozoa likely aid cellulytic bacteria and, thus, NDF digestion indirectly in vivo (Karnati et al., 2009). As a net result in the current study, dietary CNO of $2.7 \%$ or more resulted in reduced total tract $\mathrm{NDF}$ digestion and $\mathrm{eCH}_{4}$ emissions simultaneously.

Dietary CNO treatment did not decrease apparent total tract digestibilities of dietary constituents other than NDF (Table 4). Thus, we speculate that the corresponding $\mathrm{eCH}_{4}$ emissions remained steady. This ex- plains, in part, why $\mathrm{eCH}_{4}$ emitted per unit of digested $\mathrm{NDF}$ in the total tract increased as the dietary concentration of CNO increased and the amount of NDF digested decreased. The slight increase in apparent total tract starch digestibility with increasing dietary $\mathrm{CNO}$ concentrations may be indicative of greater ruminal starch digestion and lead to less production of metabolic hydrogen and consequent incorporation into $\mathrm{eCH}_{4}$. However, the overall apparent starch digestibility was already considerable for cows in the control treatment, and the increase in apparent digestibility did not compensate for decreased starch intake.

Effect on DMI and MY. Concentrations of CNO of $2.7 \%$ or greater lowered DMI and DE intake, and subsequently MY (Tables 3 and 5). These are common responses to inclusion of sources of MCFA in ruminant diets (Reveneau, 2008; Hristov et al., 2011; Hollmann and Beede, 2012). Furthermore, these responses were attributable specifically to dietary MCFA and not the general inclusion of dietary fats based on comparisons with dietary LCFA (Dohme et al., 2004; Reveneau, 2008; Hollmann and Beede, 2012). The specific metabo- 


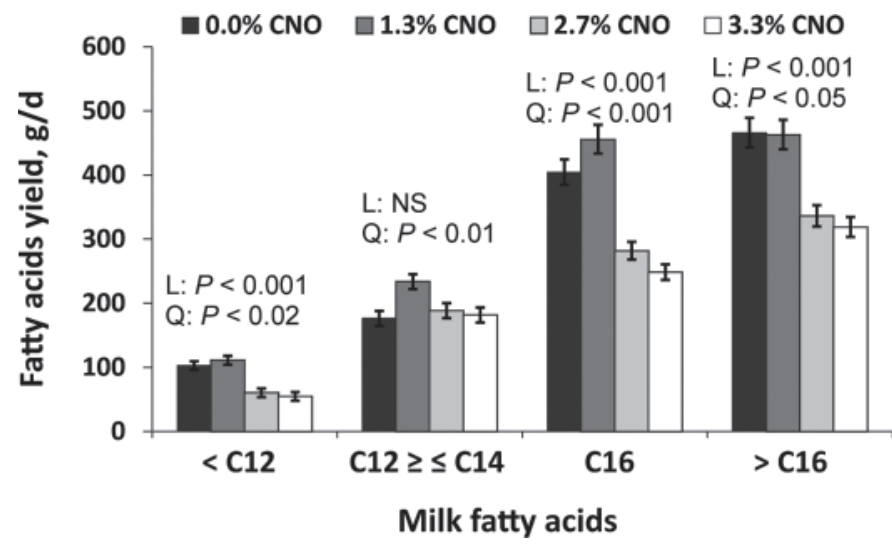

Figure 2. Effects of dietary concentrations of coconut oil (CNO) on FA yields in milk fat. L: linear effect and Q: quadratic effect of dietary $\mathrm{CNO}$ concentration. Error bars = SEM. NS: nonsignificant at $P>0.20$.

lism and partitioning of energy of MCFA presumably contributes to the DMI depression by dietary MCFA (Allen et al., 2009; Hollmann and Beede, 2012).

Nutrient Efficiencies and Enteric $\mathrm{CH}_{4}$ Emissions. Dietary concentrations of CNO of 2.7 and $3.3 \%$ decreased $\mathrm{eCH}_{4}$ emissions by 37 and $45 \%$, respectively, compared with no dietary CNO (Table 3). However, production and efficiency of feed conversion are the determining factors of farm profitability (VandeHaar, 1998). Improvement in $\mathrm{eCH}_{4}$ emissions in $\mathrm{CNO} 2.7$ and CNO3.3 was less when it was expressed based on productivity (SCMY; Table 3) or feed conversion (DMI and DM apparently digested; Table 4). Moreover, dietary CNO intensified $\mathrm{eCH}_{4}$ emissions per unit of NDF digested. It is important to take into account that these ratios do not consider additional environmental risk factors (e.g., $\mathrm{eCH}_{4}$ emissions from nonlactating cattle) based on a larger herd of dairy cattle to maintain the same overall milk production. Such a holistic approach will presumably further diminish any benefits of reducing $\mathrm{eCH}_{4}$ emissions with dietary $\mathrm{CNO}$ treatment (Hollmann and Beede, 2010). If mitigation of $\mathrm{eCH}_{4}$ emissions is due to decreased digestion of dietary fiber, then this diminishes a major advantage of ruminants versus nonruminants in food production systems. In contrast, inclusion of $1.3 \%$ dietary $\mathrm{CNO}$ lowered $\mathrm{eCH}_{4}$ emitted per unit of SCMY produced, yet not to the extent of CNO2.7 and CNO3.3. Unlike the higher CNO concen-

Table 7. Effects of dietary concentration of coconut oil (CNO) on milk FA profile

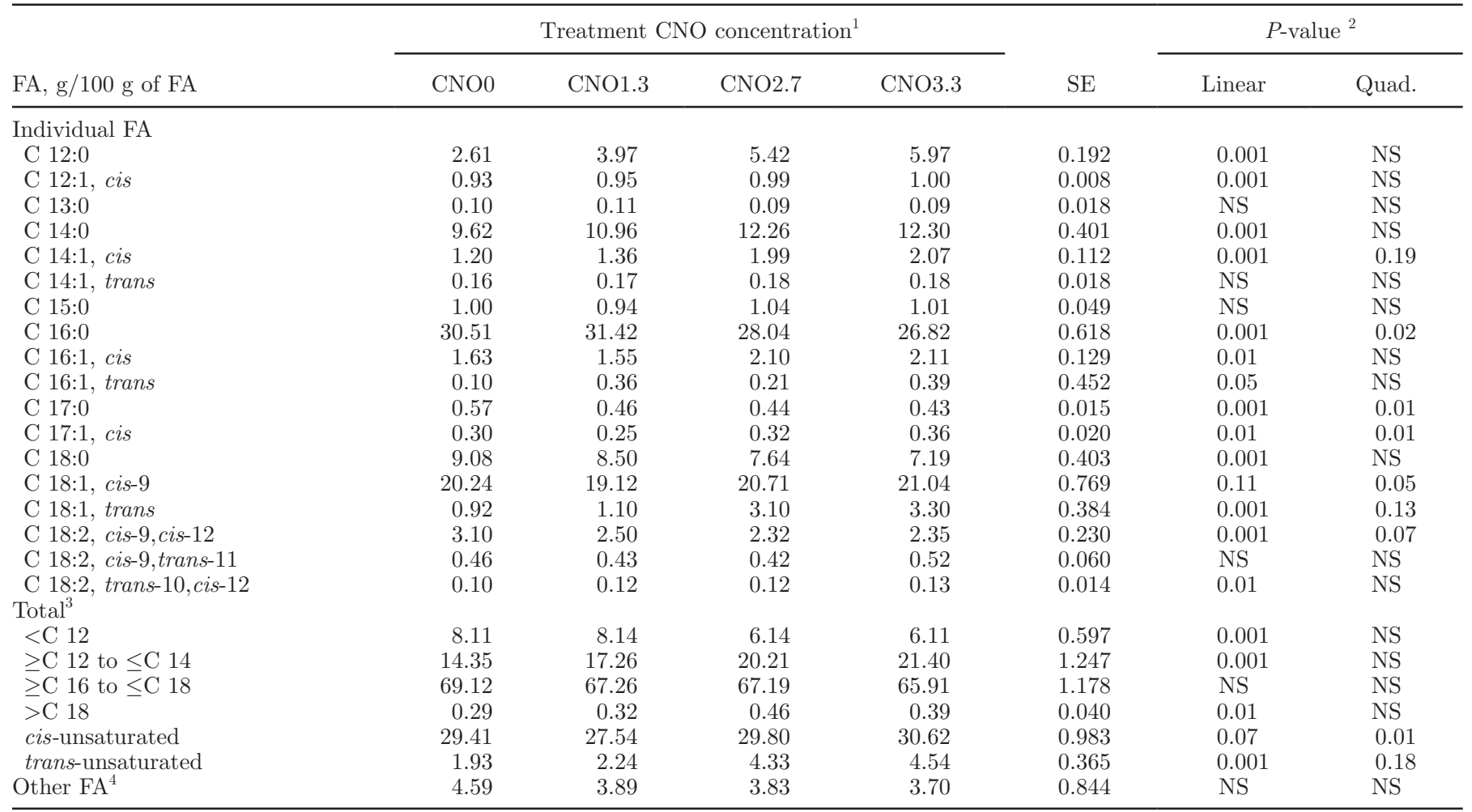

\footnotetext{
${ }^{1}$ Treatments were $0,1.3,2.7$, and $3.3 \%$ CNO in total dietary DM.

${ }^{2} P$-values correspond to orthogonal contrasts of linear and quadratic (Quad.) effect of dietary concentration of CNO. NS: $P>0.20$.

${ }^{3}$ Includes FA identified, but not individually listed above.

${ }^{4} \mathrm{FA}$ not identified and not included above.
} 
trations, CNO1.3 improved SCMY and had little, if any effect on NDF digestibility or energy intake. This may be due to general benefits of dietary fats in lactating cow diets or specific benefits from MCFA. For example, uptake of preformed dietary MCFA (Figure 2) increased milk fat yield and SCMY (Table 3) of cows fed CNO1.3. Moreover, MCFA are readily oxidized in tissues (McGarry et al., 1977) and may spare energy for milk production.

Conversion Efficiency of Dietary Protein. Partial defaunation of the rumen has been proposed to enhance the efficiency of microbial protein synthesis and decrease urinary $\mathrm{N}$ losses (Koenig et al., 2000; Hristov and Jouany, 2005). However, using CNO as a defaunation agent decreases DMI and ruminal NDF digestion, thus limiting ruminal microbial protein synthesis (Firkins et al., 2007). Dietary CNO decreased milk true protein yield and concentration (Table 3; Storry et al., 1974; Reveneau, 2008). Moreover, we are unaware of any studies in which dietary MCFA increased milk true protein yield or concentration. Dietary CP was generally fed above requirements in all experiments; thus, dietary $\mathrm{CP}$ was probably not the limiting factor to microbial protein synthesis (Firkins et al., 2007). Defaunation potentially may only improve production response in diets with marginal or deficient CP concentration (Bird et al., 1979). Indeed, the increased milk urea-N and decreased milk true protein concentrations with increased CNO concentration in the current experiment (Table 3) indicated that ruminal $\mathrm{N}$ availability was not likely to limit microbial synthesis.

\section{Apparent Digestion of FA and EE}

Increased dietary $\mathrm{CNO}$ concentration increased EE intake and amount of EE apparently digested (Table 4). Interestingly, apparent EE digestibility increased with increased CNO concentration. However, the true digestibility for $\mathrm{EE}$ is likely underestimated in diets with little or no added fat, because duodenal flow of $\mathrm{EE}$ is often greater than EE intake due to microbial FA synthesis (Doreau and Ferlay, 1994). Furthermore, microbial FA synthesis in the large intestine is likely increased with the increase in hindgut fermentation (Doreau and Ferlay, 1994) that presumably occurred with increased dietary CNO concentration. Thus, the present improvement in apparent total tract EE digestibility may not indicate an increase in true digestibility of EE. Additionally, portions of EE in the non-FA lipids of forages are poorly digestible, which likely accentuated the decreased total tract EE digestibility with less or no added CNO.

Feeding of CNO increased the intakes of and amounts of apparently digested $\mathrm{C}_{8: 0}$ to $\mathrm{C}_{14: 0} \mathrm{FA}$ relative to the control (Table 6 ). In particular, $\mathrm{C}_{8}$ and $\mathrm{C}_{10} \mathrm{FA}$ and portions of $\mathrm{C}_{12}$ FA pass epithelia freely (Hagemeister et al., 1979) without the need of incorporation into micelles, as discussed elsewhere (Hollmann and Beede, 2012). Furthermore, intestinal absorption with supplementation of FA decreased as chain length increased from $\mathrm{C}_{10}$ to $\mathrm{C}_{12}$ to $\mathrm{C}_{14}$ to $\mathrm{C}_{18}$ in the rat (Bloom et al., 1951) or from $\mathrm{C}_{12}$ to $\mathrm{C}_{14}$ to $\mathrm{C}_{18}$ in lactating dairy cows (Dohme et al., 2004). Apparent digestibilities of FA decreased as chain length increased (Table 6), yet apparent digestibilities of FA that are incorporated into microbial lipids (predominantly $\mathrm{C}_{16}$ and $\mathrm{C}_{18} \mathrm{FA}$ ) were likely underestimated as discussed above for EE. In stark contrast to the present results, intestinal absorption of FA in ruminants was approximately 10 and 15 percentage units greater for $\mathrm{C}_{16}$ and $\mathrm{C}_{18} \mathrm{FA}$ compared with $\mathrm{C}_{14}$ and $\mathrm{C}_{12}$, respectively, (Doreau and Ferlay, 1994), yet those experimental diets contained only low concentrations of $\mathrm{C}_{12}$ and $\mathrm{C}_{14} \mathrm{FA}$. Moreover, the absorption of MCFA in ruminants is mostly unknown; however, absorption of FA shorter than or equal to $\mathrm{C}_{12}$ anterior to the duodenum is possible (Hagemeister et al., 1979).

\section{Milk FA Secretion}

Dietary CNO concentrations of $2.7 \%$ or more depressed milk fat secretion and concentration (Table 3). This response was specific to CNO or MCFA, as CNO depressed milk fat compared with LCFA (Reveneau, 2008). Increased dietary CNO concentration increased the concentration of $\mathrm{C}_{18: 2 \text { trans } 10 \text {,cis-12 }}$ in milk fat, which has been associated with MFD (Bauman and Griinari, 2003). Generally, increased concentrations of $\mathrm{C}_{18: 2}$ trans10,cis-12 and trans- $\mathrm{C}_{18: 1}$ in milk fat are a result of changes in the pathways of ruminal biohydrogenation. Risk factors, such as high ruminal availability of starch and low dietary NDF or forage concentration, can result in those alternative pathways of biohydrogenation (Lock, 2010). However, ruminal availability of starch presumably varied little in the present experiment, whereas ruminal NDF digestion was impaired with CNO treatment. Thus, it is likely that the decreased ratio of ruminally digested NDF to starch causes changes in ruminal biohydrogenation (e.g., a shift to $\mathrm{C}_{18: 2 \text { trans- }}$ 10,cis-12 production), which consequently caused MFD. Moreover, MCFA may inhibit directly methanogenesis (Machmüller, 2006), which, in turn, may limit ruminal NDF digestion to avoid ruminal accumulation of hydrogen ions. Decreased counts of protozoa in ruminal contents were associated with MFD (Reveneau, 2008). Therefore, protozoa may be a factor in ruminal biohydrogenation. Nonetheless, it is not clear whether MCFA affect changes in biohydrogenation indirectly via the depression in ruminal NDF digestion or via a direct ef- 
fect on ruminal microbes. Yet, MFD is often associated with a low ratio of ruminally digested NDF to starch, such as in diets with high starch, low NDF, or low physically effective NDF (resulting in increased passage rate of NDF in small particles; Lock, 2010). The low ratio of ruminally digested NDF to starch is consistent with results in the current study.

In agreement with our previous observations (Hollmann and Beede, 2012), the decrease in milk fat secretion was based on FA synthesized de novo in the mammary gland $\left(<\mathrm{C}_{12}\right)$ and preformed FA taken up by the mammary gland $\left(>\mathrm{C}_{16}\right.$; Figure 2$)$. In contrast, net secretion of milk $\mathrm{FA} \mathrm{C}_{12}$ to $\mathrm{C}_{14}$ was similar between CNO0, and CNO2.7 and CNO3.3. Limitations in de novo synthesis of these FA with dietary CNO treatment likely were counterbalanced with utilization of preformed, dietary FA. Remarkably, the highest milk fat secretion in CNO1.3 was predominantly based on an increase in secretion of $\mathrm{C}_{12}$ to $\mathrm{C}_{14}$. Apparently, the $\mathrm{CNO}$ intake was too low to indirectly reduce $\mathrm{FA}$ de novo synthesis, but supplied additional preformed $\mathrm{C}_{12}$ and $\mathrm{C}_{14}$. The increases in milk fat concentrations of $\mathrm{C}_{12}$ and $\mathrm{C}_{14}$ with increasing intakes of these FA (Table 7) are in concert with previous reports (Reveneau, 2008; Hollmann and Beede, 2012). Increased concentrations of $\mathrm{C}_{12}$ or $\mathrm{C}_{14}$ may have implications to human health. Currently, this is an active and controversial area of research in human nutrition (Lock and Bauman, 2011).

\section{CONCLUSIONS}

Dietary CNO concentration of $2.7 \%$ or more, DM basis, reduced $\mathrm{eCH}_{4}$ emissions from high-producing dairy cows. However, reductions in $\mathrm{eCH}_{4}$ emissions also decreased DMI and NDF digestibility. As a result, MY and SCMY, and importantly also $\mathrm{eCH}_{4}$ emitted per unit of SCMY produced, were decreased. Milk true protein yield and concentration were also reduced with CNO treatment. Furthermore, impaired NDF digestion coincided with MFD based on decreased de novo synthesis of FA and secretion of preformed LCFA. In contrast, $\mathrm{eCH}_{4}$ emitted per unit of milk energy produced was lowest, milk and milk fat yields were highest, and conversion of DE into milk energy was greatest for cows fed $1.3 \%$ dietary CNO. Thus, moderate dietary concentration of CNO (1.3\%) was not detrimental to lactational performance. Nonetheless, $1.3 \%$ dietary $\mathrm{CNO}$ did not decrease $\mathrm{eCH}_{4}$ emitted per cow. Overall, dietary $\mathrm{CNO}$ at a concentration of $2.7 \%$ or greater reduced $\mathrm{eCH}_{4}$ emissions, but with great concessions in fiber utilization and milk production. Thus, the benefits of mitigation of $\mathrm{eCH}_{4}$ in lactating dairy cows with dietary CNO or MCFA must be evaluated holistically on a regional or national dairy herd basis. If mitigation of enteric $\mathrm{CH}_{4}$ emissions is due to decreased digestion of dietary fiber, then this would diminish a major advantage of ruminants compared with nonruminants to produce human-edible protein and energy.

\section{ACKNOWLEDGMENTS}

We thank West Central Cooperative (Ralston, IA) for the donation of SoyPLUS. We also appreciate the support of R. E. Kreft and the farm crew at the Michigan State University Dairy Teaching and Research Center and of B. Story at the Michigan State University Feed Mill. S. Hengemuehle, D. G. Main, L. E. Gault, K. M. Lebbin, O. N. Genther, N. Schroeder, and S. M. Carrier in the Animal Science Department and J. A. Zyskowski at the Nutrition Laboratory (Diagnostic Center for Population Animal Health at Michigan State University) provided technical assistance. Numerous undergraduate students assisting with animal care, data collection, sample preparation, and parts of the laboratory analyses were indispensible.

\section{REFERENCES}

Aguerre, M. J., M. A. Wattiaux, J. M. Powell, G. A. Broderick, and C. Arndt. 2011. Effect of forage-to-concentrate ratio in dairy cow diets on emission of methane, carbon dioxide, and ammonia, lactation performance, and manure excretion. J. Dairy Sci. 94:30813093.

Allen, M. S., B. J. Bradford, and M. Oba. 2009. The hepatic oxidation theory of the control of feed intake and its application to ruminants. J. Anim. Sci. 87:3317-3334.

AOAC (Association of Analytical Chemists). 1990. Official Methods of Analysis. Vol. 2. 15th ed. AOAC, Arlington, VA.

Bauman, D. E., and J. M. Griinari. 2003. Nutritional regulation of milk fat synthesis. Annu. Rev. Nutr. 23:203-227.

Beauchemin, K. A., M. Kreuzer, F. O'Mara, and T. A. McAllister. 2008. Nutritional management for enteric methane abatement: A review. Aust. J. Exp. Agric. 48:21-27.

Bird, S. H., M. K. Hill, and R. A. Leng. 1979. The effects of defaunation of the rumen on the growth of lambs on low-protein-highenergy diets. Br. J. Nutr. 42:81-87.

Blaxter, K. L., and J. L. Clapperton. 1965. Prediction of amount of methane produced by ruminants. Br. J. Nutr. 19:511-522.

Blaxter, K. L., and J. Czerkawski. 1966. Modifications of the methane production of the sheep by supplementation of its diet. J. Sci. Food Agric. 17:417-421.

Bloom, B., I. L. Chaikoff, and W. O. Reinhardt. 1951. Intestinal lymph as pathway for transport of absorbed fatty acids of different chain lengths. Am. J. Physiol. 166:451-455.

Bradford, B. J., and M. S. Allen. 2004. Milk fat responses to a change in diet fermentability vary by production level in dairy cattle. J. Dairy Sci. 87:3800-3807.

Dohme, F., A. Machmüller, F. Sutter, and M. Kreuzer. 2004. Digestive and metabolic utilization of lauric, myristic and stearic acid in cows, and associated effects on milk fat quality. Arch. Anim. Nutr. 58:99-116.

Doreau, M., and A. Ferlay. 1994. Digestion and utilisation of fatty acids by ruminants. Anim. Feed Sci. Technol. 45:379-396.

Faciola, A. P., G. A. Broderick, A. N. Hristov, and J. A. Pires. 2008. Effect of four levels of lauric acid on ruminal protozoa, milk production and composition in dairy cows. J. Dairy Sci. 91(E-Suppl. 1):76. (Abstr.) 
Firkins, J. L., Z. Yu, and M. Morrison. 2007. Ruminal nitrogen metabolism: Perspectives for integration of microbiology and nutrition for dairy. J. Dairy Sci. 90(E.-Suppl.):E1-E16.

Goering, H. H., and P. J. Van Soest. 1970. Forage Fiber Analysis (Apparatus, Reagents, Procedures, and Some Applications). Agric. Handbook No. 379. Agricultural Research Service-US Department of Agriculture, Washington, DC.

Hach, C. C., B. K. Bowden, A. B. Kopelove, and S. V. Brayton. 1987. More powerful peroxide Kjeldahl digestion method. J. Assoc. Off. Anal. Chem. 70:783-787.

Hagemeister, H., W. Kaufmann, and A. Wiechen. 1979. Determination of the resorption sites of fatty acids in the digestive tract of dairy cows. Kieler Milchwirtschaftliche Forschung 31:5-10.

Hollmann, M., and D. K. Beede. 2010. Limited suitability of dietary coconut oil to reduce enteric methane emission from dairy cattle. Page 112 in Proc. Int. Conf. Greenhouse Gases Anim. Agric. Accessed Mar. 7, 2012. http://www.ggaa2010.org/pdfs/Proceedings_ Abstracts.pdf.

Hollmann, M., and D. K. Beede. 2012. Comparison of effects of dietary coconut oil and animal fat blend on lactational performance of Holstein cows fed a high-starch diet. J. Dairy Sci. http://dx.doi. org/10 3168/jds2011-4792.

Hristov, A. N., and J.-P. Jouany. 2005. Factors affecting the efficiency of nitrogen utilization in the rumen. Pages 117-166 in Nitrogen and Phosphorus Nutrition of Cattle and Environment. A. N. Hristov and E. Pfeffer, ed. CAB International, Wallingford, UK.

Hristov, A. N., C. Lee, T. Cassidy, M. Long, K. Heyler, B. A. Corl, and R. Forster. 2011. Effects of lauric and myristic acids on ruminal fermentation, production, and milk fatty acid composition in lactating dairy cows. J. Dairy Sci. 94:382-395.

Hristov, A. N., M. Vander Pol, M. Agle, S. Zaman, C. Schneider, P. Ndegwa, V. K. Vaddella, K. Johnson, K. J. Shingfield, and S. K. R. Karnati. 2009. Effect of lauric acid and coconut oil on ruminal fermentation, digestion, ammonia losses from manure, and milk fatty acid composition in lactating cows. J. Dairy Sci. 92:55615582 .

Immig, I. 1996. The rumen and hindgut as source of ruminant methanogenesis. Environ. Monit. Assess. 42:57-72.

Johnson, K. A., R. L. Kincaid, H. H. Westberg, C. T. Gaskins, B. K. Lamb, and J. D. Cronrath. 2002. The effect of oilseeds in diets of lactating cows on milk production and methane emissions. J. Dairy Sci. 85:1509-1515.

Jordan, E., D. K. Lovett, M. Hawkins, J. J. Callan, and F. P. O'Mara. 2006. The effect of varying levels of coconut oil on intake, digestibility and methane output from continental cross beef heifers. Anim. Sci. 82:859-865.

Karkalas, J. 1985. An improved enzymatic method for the determination of native and modified starch. J. Sci. Food Agric. 36:10191027.

Karnati, S. K. R., J. T. Sylvester, C. V. D. M. Ribeiro, L. E. Gilligan, and J. L. Firkins. 2009. Investigating unsaturated fat, monensin, or bromoethanesulfonate in continuous cultures retaining ruminal protozoa. I. Fermentation, biohydrogenation, and microbial protein synthesis. J. Dairy Sci. 92:3849-3860.

Külling, D. R., F. Dohme, H. Menzi, F. Sutter, P. Lischer, and M. Kreuzer. 2002. Methane emissions of differently fed dairy cows and corresponding methane and nitrogen emissions from their manure during storage. Environ. Monit. Assess. 79:129-150.
Koenig, K. M., C. J. Newbold, F. M. McIntosh, and L. M. Rode. 2000. Effects of protozoa on bacterial nitrogen recycling in the rumen. J. Anim. Sci. 78:2431-2445.

Li, W., W. Powers, and G. M. Hill. 2011. Feeding DDGS to swine and resulting impact on air emissions. J. Anim. Sci. 89:3286-3299.

Lock, A. L. 2010. Update on dietary and management effects on milk fat. Pages 15-26 in Proc. Tri-State Dairy Nutr. Conf., Fort Wayne, IN. The Ohio State University, Columbus.

Lock, A. L., and D. E. Bauman. 2011. Milk fat and human healthSeparating fats from fiction. Pages 126-135 in Proc. Cornell Nutr. Conf. Feed Manuf., East Syracuse, NY. Cornell University, Ithaca, NY.

Machmüller, A. 2006. Medium-chain fatty acids and their potential to reduce methanogenesis in domestic ruminants. Agric. Ecosyst. Environ. 112:107-114.

Matsumoto, M., T. Kobayashi, A. Takenaka, and H. Itabashi. 1991 Defaunation effects of medium-chain fatty acids and their derivatives on goat rumen protozoa. J. Gen. Appl. Microbiol. 37:439445 .

McGarry, J. D., G. P. Mannaerts, and D. W. Foster. 1977. A possible role for malonyl-CoA in the regulation of hepatic fatty acid oxidation and ketogenesis. J. Clin. Invest. 60:265-270.

NRC. 2001. Nutrient Requirements of Dairy Cattle. 7th ed. National Academic Press, Washington, DC.

Odongo, N. E., M. M. Or-Rashid, E. Kebreab, J. France, and B. W. McBride. 2007. Effect of supplementing myristic acid in dairy cow rations on ruminal methanogenesis and fatty acid profile in milk. J. Dairy Sci. 90:1851-1858.

Reveneau, C. 2008. Dietary source and availability of fatty acids to manipulate ruminal protozoa, metabolism of fat, and milk fatty acid profile in lactating dairy cows. PhD Dissertation. The Ohio State Univ., Columbus.

Rindsig, R. B., and L. H. Schultz. 1974. Effect of feeding lauric acid to lactating cows on milk composition, rumen fermentation, and blood lipids. J. Dairy Sci. 57:1414-1419.

Storry, J. E., P. E. Brumby, A. J. Hall, and V. W. Johnson. 1974. Response of the lactating cow to different methods of incorporating casein and coconut oil in the diet. J. Dairy Sci. 57:61-67.

Sukhija, P. S., and D. L. Palmquist. 1988. Rapid method for determination of total fatty acid content and composition of feedstuffs and feces. J. Agric. Food Chem. 36:1202-1206.

Sun, H., S. L. Trabue, K. Scoggin, W. A. Jackson, Y. Pan, Y. Zhao, I. L. Malkina, J. A. Koziel, and F. M. Mitloehner. 2008. Alcohol, volatile fatty acid, phenol, and methane emissions from dairy cows and fresh waste. J. Environ. Qual. 36:615-622.

Sutton, J. D., R. Knight, A. B. McAllan, and R. H. Smith. 1983. Digestion and synthesis in the rumen of sheep given diets supplemented with free and protected oils. Br. J. Nutr. 49:419-432.

Tyrrell, H. F., and J. T. Reid. 1965. Prediction of the energy value of cow's milk. J. Dairy Sci. 48:1215-1223.

Van Soest, P. J., J. B. Robertson, and B. A. Lewis. 1991. Methods for dietary fiber, neutral detergent fiber, and nonstarch polysaccharides in relation to animal nutrition. J. Dairy Sci. 74:3583-3597.

VandeHaar, M. J. 1998. Efficiency of nutrient use and relationship to profitability on dairy farms. J. Dairy Sci. 81:272-282.

Verdi, R. J., D. M. Barbano, M. E. Dellavalle, and G. F. Senyk. 1987. Variability in true protein, casein, nonprotein nitrogen, and proteolysis in high and low somatic cell milks. J. Dairy Sci. 70:230-242 